\title{
Rock Features and Alteration of Stone Materials Used for the Built Environment: A Review of Recent Publications on Ageing Tests
}

\author{
Carlos Alves ${ }^{1, * \mathbb{C}}$, Carlos Figueiredo ${ }^{2} \mathbb{D}$ and Jorge Sanjurjo-Sánchez ${ }^{3}$ \\ 1 LandS/Lab2PT-Landscapes, Heritage and Territory laboratory (FCT-AUR/04509) and Earth Sciences \\ Department/School of Sciences, University of Minho, 4710-057 Braga, Portugal \\ 2 CERENA-Centro de Recursos Naturais e Ambiente, FCT- UID/ECI/04028/2019, DEcivil, Instituto Superior \\ Técnico, University of Lisbon, 1049-001 Lisbon, Portugal; carlos.m.figueiredo@ist.utl.pt \\ 3 University Institute of Geology, Universidade da Coruña, ESCI, Campus de Elviña, 15071 A Coruña, Spain; \\ jorge.sanjurjo.sanchez@udc.es \\ * Correspondence: casaix@dct.uminho.pt
}

Received: 30 December 2019; Accepted: 26 February 2020; Published: 28 February 2020

\begin{abstract}
This work presents a review of recent publications, with publication date between 2017 and 2019, with information on the relation between rock characteristics and the effects of diverse agents associated with alteration of stone materials in the built environment. It considers information obtained from ageing tests performed under laboratory conditions and by exposure to outdoor agents. Several lithological groups were considered, with sedimentary carbonate rocks being the most frequently studied lithotypes and silicate metamorphic rocks being the group with scarcer information. In terms of ageing tests, salt weathering was the most frequent one while there was a noticeable lesser amount of information from tests with biological colonization. The collected data showed the influence of diverse features, from specific minerals to whole-rock properties and the presence of heterogeneities. These information are discussed in the context of formulating a general framework for stone decay.
\end{abstract}

Keywords: salt weathering; mineralogy; structural-textural characteristics; porous media

\section{Introduction}

Stone is an important component of the cultural heritage and still going strong as a building material, with around 2.8 million tons of dimension stone sold in 2018 in the United States alone [1].

The interactions between stone materials and diverse agents in the built environment can lead to, in general, unwanted alteration features. The term "alteration" is used here in a wide sense to encompass all unintended transformations that the stone suffers because of the agents in the built environment such as salts, water, ice, biological colonization, atmospheric pollution, etc. The alteration of stone after emplacement in built structures has been noticed at least since the time of Herodotus, who reported the occurrence of efflorescence of salt in Egypt and remarked that "even the pyramids are being eaten away by it" [2]. Comments on stone characteristics relevant to their performance in buildings were also presented in Vitruvius classic work [3], which has what was possibly the first proposal for tests to assess stone durability using an exposure test. While the test proposed by Vitruvius used field conditions, the time range proposed by this author is not compatible with building projects and diverse accelerated ageing tests have been devised using the agents usually identified in the alteration of building materials.

General concepts concerning the alteration processes that affect stone applied in the built environment can be found in Siegesmund and Snethlage [4]. While there are several reviews concerning 
alteration agents such as atmospheric pollution [5], soluble salts [6], and biological agents [7], the effects of rock characteristics have deserved less attention.

This review attempts to present a snapshot of recent trends in what can be called the petrological side of natural stone alteration and we did not consider results from tests with artificial stone. The potential interest of this line of research is, in our opinion, two-fold:

To help in the diagnosis of the causes promoting the alteration of natural stone in the built environment, in order to help in the design of suitable intervention measures;

To contribute to define criteria for the selection of suitable stone materials for application in the built environment, also according to the alteration agents that could affect these materials.

\section{Dataset}

This review considers publications found in the Scopus database, with publication date from 2017 onward and that present empirical results from ageing tests with natural stone. We considered only studies performed under laboratory conditions or by exposure to outdoor conditions given that in these cases there would be information regarding time and some control in relation to the initial conditions. While there were many other publications concerning the alteration of stones in the built environment during the aforementioned period, we collected information from 74 publications [8-81] that presented experimental results on the interaction between rock features and ageing agents, and that will be discussed in the following sections. This document was prepared with Google online software (Google Docs and Google Sheets) and with additional editing with the open-source freeware LibreOffice (https://www.libreoffice.org) and Inkscape (https://inkscape.org).

\section{Rocks and Tests}

Here is presented a first analysis of the considered dataset with some general information in relation to the types of rocks and the tests that were used for simulating the alteration processes.

\subsection{Lithological Diversity}

The rocks mentioned in the publications were distributed (Figure 1) by the following general lithological groups:

- SC, sedimentary carbonate rocks (mostly diverse types of limestones and including, travertines, carbonate tufas and dolostones);

- $\mathrm{SD}$, sedimentary detrital rocks, a group that in the studied set corresponds to arenaceous rocks;

- P, pyroclastic rocks;

- M, magmatic rocks (which include plutonic and lava rocks);

- $\mathrm{MC}$, metamorphic carbonate rocks (in the data collected all occurrences correspond to marbles);

- MS, metamorphic silicate (with diverse crystals-sizes and composition, from slates to gneiss, and including serpentinites).

The plot represents the percentage of the studied publications that consider a given group, hence some publications will be counted more than once (e.g., if they studied a granite and a limestone) and the sum of the values will be higher than 100 . More petrological details will be given in the discussion of the relations with alteration tests. It is clear that sedimentary carbonate rocks are dominant in this dataset while, on the other extreme, silicate metamorphic rocks are scarcely represented. While the plot of Figure 1 gives an indication of the lithological diversity of the studied dataset, it does not show the specific rocks considered in each publication. This will be more developed in the discussion of Section 4 but even that might fail to reveal the extension of some works such as, e.g., Ahmad et al. [8], which consider 12 types of plutonic and metamorphic rocks and Pötzl et al. [47], which studied 14 types of tuff. 


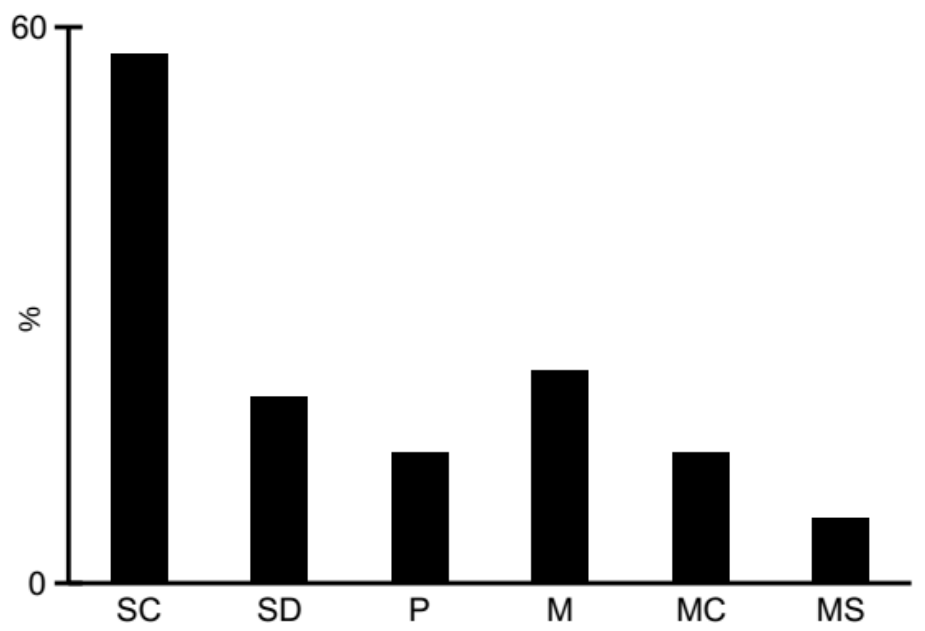

Figure 1. Lithological diversity of the analyzed publications considering the following broad groups: SC: sedimentary carbonate rocks; SD: sedimentary detrital rocks; P: pyroclastic rocks; M: magmatic rocks; MC: metamorphic carbonate rocks; MS: metamorphic silicate.

\subsection{Ageing Tests}

Figure 2 presents a plot that attempts to show the kind of agents that were used in the analyzed publications to promote the alteration of the rock specimens, again as a percentage of the dataset. The sum of the frequency values, again, gives a value above 100 , since some publications consider more than one agent, such as salt weathering and freeze-thaw.

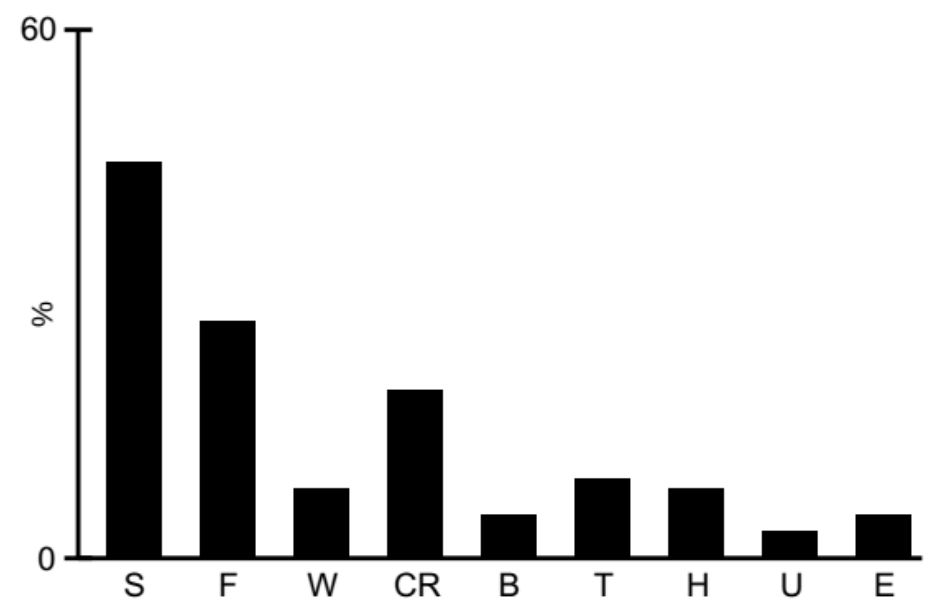

Figure 2. Ageing tests of which data were collected from the publications considered, S: salt weathering; F: freeze-thaw; W: wetting-drying; CR: chemical reactants; B: biological colonization; (see text for more information); $\mathrm{T}$ : thermal cycles; $\mathrm{H}$ : heating; $\mathrm{U}$ : exposure to ultraviolet radiation; E: exposure to weathering agents in the outdoors.

In this general review, we are considering under "S" all salt weathering tests, regardless of the variations in terms of the type of salt, salt content, imbibition procedure, and environmental conditions, namely drying temperature. The groups " $\mathrm{F}$ " (freeze-thaw), " $\mathrm{T}$ " (thermal cycles), and " $\mathrm{H}$ " are all related to temperature variations but the first one mostly concerns the effects of volumetric variations of water in pores and, therefore, is akin of the salt weathering tests. The group referred to

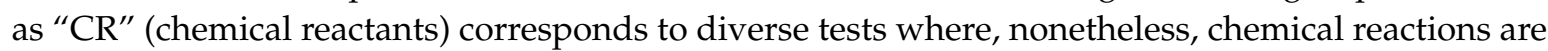
dominant, whether related to atmospheric pollution (solution, gases, and particles) or to dissolution and leaching by solutions, including slake tests. In this organization, we are assuming that water or 
salt solutions do not cause significant chemical changes. The group represented as " $\mathrm{B}$ " corresponds to tests designed to promote biological colonization but exposure tests, " $\mathrm{E}$ ", can also promote this kind of result. As will be seen below, the kind of effects resulting from heating (" $\mathrm{H}$ ") and thermal shocks and cycling ("T") are quite different, given, namely, that the first kind of test involves higher temperatures. We are assuming that the thermal effects of wet-dry tests ("W") and salt weathering tests were negligible, which can be controversial, especially for the later. Of course, one can also posit that both salt weathering tests and freeze-thaw tests include a wetting-drying component.

Salt weathering is clearly the most frequent kind of ageing test considered in the publications analyzed, followed by freeze-thaw. It is also noteworthy the relatively small proportion of publications concerning the effects of chemical pollutants and, most strikingly, the proportion that considers tests promoting biological colonization (however, tests involving the exposure to outdoor agents might be influenced by both).

\section{Effects of Ageing Tests on Rock Features}

This section presents the information collected on the effects of ageing tests on specific rock features, including mineralogical, textural, structural, and pore system characteristics, as well as (bulk) physical properties, including mechanical properties. In some cases, results concern one feature but in others, the authors propose potential relations to several factors.

\subsection{Minerals and Other Phase Constituents}

The characteristics of some minerals and other constituent phases have been indicated as contributing to the alterations of stone materials. Some mineral phases are particularly susceptible to dissolution such as calcite, which was studied by tests with acid rain solutions [30] and the occurrence of high magnesium calcite and aragonite was considered to favor dissolution of limestones [17]. Also in limestones, there is reference to the susceptibility of calcite to biological action [63]. The anisotropic behavior to the dissolution of calcite has been reported as having an impact on the surface reactivity of marbles [69]. Some studies have also found etching of calcite crystals resulting from limestone heating [22]. Experiments with burying in guano, which can have saline and acid effects, have described reactivity of lithologies with calcium phases in limestone and basalt [9]. According to Deng et al. [36], clay minerals can react with acid solutions, enhancing the microporosity and susceptibility to freeze-thaw of sandstones.

There are also references to the reactivity of non-crystalline constituents, such as the dissolution of organic matter in limestone under salt weathering [35] and the susceptibility of carbon-rich slates to microorganisms [19].

In a somewhat opposite direction, there are indications that dolomite crystals in marbles were less susceptible to the action of microorganisms [11] and that the presence of dolomite in limestones contributed to higher resistance to dissolution with water [17]. The higher resistance to salt weathering tests of dolomitic marbles, in relation to calcitic ones, has been attributed to the lower solubility of dolomite, when compared with calcite, in salt solutions [23].

Oxidation processes can contribute to stains in limestone because of the action of salt solutions [71] and acid solutions [38], with this last publication also reporting the oxidation of iron-containing calcite.

Physical agents can interact also with the characteristics of the minerals that are present in a rock. The presence of phyllosilicates has been considered to contribute to the susceptibility of arenaceous sedimentary rocks to salt weathering [50,56] and to wetting-drying [77], with these last authors proposing different impact for different clay minerals according to moisture content.

Biotite was found to be more susceptible to the development of fissures under stress conditions that promoted crack propagation in kersantite specimens [55]. Ultraviolet exposure tests have been reported as causing oxidation effects on sandstones exposed to the outdoors [12].

Alterations effects associated with thermal cycles have been indicated, namely in relation to calcite volumetric variations [78]. We can include in these considerations also a study that presented 
observations of slight bowing of magmatic rocks under thermal cycles [51]. There are also studies explaining mass loss in tuff and andesite as resulting from mineralogical changes associated with loss of interstitial water of layered minerals because of gas temperature under conditions simulating atmospheric pollution [64].

Chromatic changes resulting from heating have been reported for clay minerals in sandstones [40] and in limestone [27], and for biotite, amphiboles, garnet, alkaline feldspars, chlorite, and quartz in granitoids [68], and these authors also refer to the influence of the content in biotite and plagioclase on the rock physical damage by cracking.

\subsection{Pore Network Features}

Pores frequently favor the decay effects of diverse agents. In a study promoting biological colonization of limestones, microorganisms were detected inside pores, which was explained for pores being places with higher moisture [34]. In a limestone subjected to gaseous attack, the network of macropores allowed the penetration of gases and in-depth reactions [39] and it has been observed the enlargement by salt weathering of macropores and existing fissures in trachyte [15].

Higher porosity is often considered to promote stone susceptibility to alteration processes in the built environment and $10 \%$ porosity was implied as a kind of threshold for susceptibility to salt and ice weathering of the travertines and carbonate tufas studied by Benavente et al. [33], because of higher pore interconnection and fluid migration but this cannot be considered a universal rule, as the results of many other rocks have shown.

Some studies have shown the higher susceptibility to salt weathering of more porous limestones [17,35,50], with similar results for granites [28] and for highly porous sandstones [53]. The same trend has been obtained in terms of the effects of acid solutions on limestones [38,44].

Similar trends have been observed in the comparison of different lithologies in salt weathering tests, with a more porous granite behaving worse than a limestone with lower porosity [73]. Higher biological colonization has also been observed on more porous types, with worse results for limestone than for marble [10] and for limestone than granite [59]. The penetration of soot was found [64] to be higher for the more porous lithologies (rhyolite tuff, travertine, granite and the more porous limestone) while deep penetration of particles was not observed by visual inspection on other rocks with more dense structure (andesite, marble, sandstone, and a less porous limestone). There is a report of higher susceptibility to sulfation of travertine than marble, being the porosity of the travertine higher [54].

Higher porosity, by promoting higher pollutants loads, can also furthermore contribute to other decay processes. According to the study by Thomachot-Schneider et al. [76], the thermal response of limestones that absorb more salts due to higher porosity contributed to the disaggregation of these stone types.

However, there are references to the opposite for limestones, pointing that lower porosity promotes higher sensibility in the case of alteration because of thermal effects [17,22]. In a comparison of limestone and granite, higher increase in porosity was found for limestone than for granite, porosity being lower in limestone [73]. On the other hand, there is at least one study explaining the slight impact of thermal shock on a limestone by the low porosity of this rock [18]

Besides the total amount of pores, the dimensions of the pores have been considered. In freeze-thaw tests with diverse rock types (basalt, diabases, dolostones, gneiss, granite, limestones, and sandstone), susceptibility was higher for high porosity rocks but was also related to a parameter based on a volumetric fraction of the pore space [26]. The effects of salt weathering on granites have been found to be related to higher porosity but also to pore-size distribution [52]. Differences in the patterns of salt weathering of two limestone types were related to differences in pore size distribution with the most affected limestone being the most porous one and the one with smaller pore size [52]. A study with several tuffs reported that those with micropores dominance were particularly affected by salt weathering [47]. But bigger pores can favor limestone dissolution by acid attack [38] and according to Fogue-Djombou et al. [65], limestones with unimodal pore network dominated by micropores present 
higher resistance to freeze-thaw than limestone with bimodal pore system. On the other hand, a study with several rock types proposed that the rocks with greater variation in pore size (limestone and travertine) were more stable under freeze-thaw tests than the others (trachyandesite and tuff) [80]. The impact of salt solutions in tuff [20] and limestone [25] has been explained by crystallization pressures resulting from pore size distribution.

It will be interesting to note that in a study of basalts, Dursun and Topal [62], found that the type with smaller pores (massive basalt) presented higher durability than the vesicular that presented higher porosity and water absorption as well as other physical characteristics (see below).

Additionally, the interconnections of the pores can affect the action of decay agents. It has been found for trachytes tested with salt weathering that higher porosity did not necessarily imply low durability since poorly interconnected pores can limit the action of water-related agents [15]. In a study of tuffs subjected to salt weathering tests [46], all types showed significant mass losses but lower resistance to salt weathering was observed for the types with higher water vapor diffusion, which was considered as an indicator of the transport of solutions.

\subsection{Textural and Structural Features}

Rocks are generally multiphase aggregates and the impact of alteration agents can be affected by the interfaces between individual particles, as well as the orientation, geometry, and space distribution patterns of those individual particles (and their variations).

The detachment and loosing of grains were observed in marbles subjected to heating-cooling and freeze-thaw tests [21]. There are also references to the action of salt and ice in interfaces between grains in sandstone [75] and in trachyandesite and tuff [80]. According to Murru et al. [45], marble (granoblastic texture) showed lower resistance to thermal shock than limestone with sparite and micrite and sparry cement has been reported as increasing durability of limestones under freeze-thaw tests [70].

The preferred orientation of calcite crystals in marbles has been considered as contributing to differential surface reactivity to pollutants of this kind of rock [69].

The action of pollutants was found to exploit finer crystals (higher specific surface) in limestones [14]. On the other hand, in heating tests of magmatic rocks, the presence of minerals with coarser size and different coefficients of thermal expansion corresponded to worse results [48]. Tuffs with different granularity have shown different decay features under tests of freeze-thaw and salt crystallization [67].

The presence of calcite and clay matrix in arenaceous sedimentary rocks seem to favor the propagation of cracks while more rigid minerals like quartz and feldspar are not affected [77]. The presence of oxides in vugs in laminated travertines promotes susceptibility to salt and ice, highlighting the effect of anisotropy in these rocks [33].

The presence of calcite cement in sandstone contributes to their susceptibility to acid attack [66] and has been related to the development of contour scaling under salt weathering [56]. Tuffs with predominance of glassy groundmass and pumice clasts presented higher susceptibility to salt weathering [67].

We found examples of the role played by heterogeneity features in alteration processes. In tests with acid attack to limestones, it was reported that ooids and fossils presented a lower resistance than the cement [38]. In a limestone subjected to acid attack, dissolution of ooids and cement did not present noteworthy differences and the voids in ooids that were present on the specimens before the test promoted sulphates and nitrates crystallization [39].

In freeze-thaw tests with limestones, growth of cracks at the interface between allochems and sparry cement and the detachment of peloids and ooids has been observed [27]. The cement between grains in sandstone was found to be affected by this kind of test [29] and also by wetting-drying cycles [60]. 
Salt weathering tests with volcanic rocks showed the effects of existing heterogeneities such as structures of preferred orientation and big pumice clasts in ignimbrites [43] and the higher susceptibility of groundmass in trachytes [15] and in tuffs [46,67]. Surface heterogeneities such as stylolites have been considered to increase the susceptibility of limestones to freeze-thaw $[16,17,65,78]$, wet-dry cycles [31] and salt weathering [17], with cracks assumed to be presented before testing also promoting the effects of these decay agents [53]. In trachytes, salt weathering affects fronts with iron oxides and hydroxides [15]. But it has been proposed that sericite and clay minerals can have a sealing effect in granite cracks, limiting water movement and diminishing the impact of salt weathering [52].

The effects of salt solutions on limestones appear to be potentiated along stratification [53] and the effects of bedding were found to be more marked for coarser portions in sandstones [53] and limestone [74].

\subsection{Multiple Factors}

This section comprises cases where the authors of the considered papers proposed more than one factor for explaining a given trend, including other bulk physical properties of rocks that were not considered in previous sections of the present publication.

Perhaps the most interesting result of those that were surveyed in the dataset studied here is the relation between mass loss in salt weathering tests and a petrographic index that includes both voids and mineralogical features, namely the relation between sound or primary minerals and secondary minerals formed by weathering [8], in a study that considered several magmatic and metamorphic silicate rocks with different weathering degree and that had a set of results that seem to comply with the necessary conditions for correlation. However, it is possible that this type of relation will not hold for rocks whose decay follow other petrographic models such as limestones and sandstones or for rocks with more chemically susceptible minerals but it must be highlighted that this is a very testable hypothesis that is particularly interesting for the geosciences since it involves petrographic criteria.

Other majorly interesting publications have data that contribute to assess the role of different factors. In the study presented by Nasri et al. [71], comparing a carbonate tufa and a limestone under salt weathering tests, the tufa showed better durability, in spite of having much lower mechanical strength and much higher porosity and water capillary absorption, even after correcting for porosity differences, a result that the authors attribute to the presence of macropores in the carbonate tufa.

In a study on tuffs under freeze-thaw and salt weathering tests [67], there were differences attributed to the pore size distribution, with smaller pores causing higher decay. However, according to the authors, this "can be considered only a secondary factor" in tuffs with lower porosity and higher tensile strength that present better results.

In a study with acid solutions, a more porous but silica richer limestone showed lower mass loss than a limestone with lower porosity but richer in calcium carbonate [44]. The presence of clay minerals can promote an incipient lamination in a low porosity limestone that favors the action of freeze-thaw [18].

The study of Dursun and Topal [62] in basalts showed higher durability for the massive basalts than for a vesicular one, with the massive type presenting smaller pore size. This result was attributed by the authors to the lower dry/wet ratio of mechanical strength of the vesicular basalt, which, however, was also the more porous basalt type.

Sato and Hattanj [49] presented a study with a tuff and two sandstones. Comparing the tuff and a sandstone with similar porosity and tensile strength, the sandstone with higher micropore volume and higher specific surface behave worse while the tuff had large pores associated with the alteration of pumice. The other sandstone with lower porosity and higher tensile strength showed also high resistance to salt weathering.

In other studies, there was a concurrence of factors in the same direction. Lower durability in freeze-thaw tests of limestones [37] and salt weathering tests of ignimbrites [24] were related to higher porosity, higher capillarity coefficient, and lower mechanical strength. The higher resistance to acid 
solutions of dolomitic limestone, when compared with calcium carbonate sedimentary rocks, has been explained by coarser texture, lower porosity, and higher mechanical strength [57]. Explanations joining mechanical strength and bulk properties of the pore system, such as porosity, water absorption, and capillarity coefficient, with higher values of microporosity have been presented for higher susceptibility to salt crystallization of travertines [81] and pyroclastic rocks, with the variations in this last study being related to welding degree [43]. A comparison of rhyodacite and andesite found the former more susceptible than andesite because of the lower strength, higher porosity, and also higher microporosity [58]. Similar results were obtained in studies of freeze-thaw tests with travertines and limestones [41]. Higher porosity and water absorption, as well as bimodal pore space with important microporosity, were proposed to explain the lower durability of a tuff in relation to another tuff and an andesite in salt weathering tests [61].

In salt weathering studies with sandstones, highest durability was indicated for the type with lowest microporosity, better cementation, lowest anisotropy (albeit it is the type with highest thermal expansion) and that is the most homogeneous one, presenting mainly quartz and without swellable minerals, while the less durable type showed higher microporosity, the presence of phyllosilicates in significant amounts and marked thermal and hydric anisotropy [56]. The loss of gloss in serpentines under ultraviolet exposure tests presented positive correlation with water absorption and negative correlations with density and mechanical strength [72]. But this same study showed higher gloss loss in serpentinites where antigorite was dominant and that higher mineralogical diversity corresponded to lower gloss loss.

Sometimes pore characteristics are associated with other textural features. For example, images of study by Török and Szemerey-Kiss [79], showed that a coarser limestone which was less porous and presented a higher percentage of fine pores presented higher erosion than a finer limestone that was more porous and had a higher percentage of the higher radii pores (in freeze-thaw tests with stone and mortars, where, hence the possibility of some salt contribution could be pondered). Bioturbation in limestones has been reported to be susceptible to salt weathering erosion because of the association with iron oxides and porosity [71]. In a study of two limestones and marble, the limestone with higher porosity and surface roughness showed higher darkening related to fixation of particulate matter and higher deposition of the soluble fraction [13]. In exposure tests, slabs of limestone showed higher deposition of sulphates than carbonate-rich sandstone and polished marble [32].

\section{Final Considerations}

In the period surveyed (2017-2019), studies concerning ageing tests of stone materials showed a clear vitality, in general, averaging two publications by month. However, a marked disparity in terms of lithological types was observed. There are many more studies with sedimentary carbonate rocks than with metamorphic silicate rocks, and information for the latter is scarce. In relation to the types of ageing tests used, there is a wide diversity but salt weathering is clearly dominant, perhaps reflecting the recognized erosive impact of soluble salts on stone materials used in built structures. One can highlight, also, the low proportion of publications with information from tests promoting biological colonization (possibly reflecting the essentially chromatic effects of this kind of agent). Hence this survey seems to suggest clear trends in terms of objects and processes. The collected information regarding the effects of ageing agents ranges from responses of specific minerals to assessments of whole-rock behavior based on one or more factors. While the former is more limited in scope, the latter shows variations and even contradictions that might be related to a pervasive case-study way of thinking, where authors are in general concerned with some particular rock types, from specific places. The usual limitations in experimental studies in terms of the available techniques and situations with confounding conditions, where several factors could contribute to the same outcome, can also contribute to the observed dispersion. 
Hence, reviews like the present one are essential to assess the state of knowledge in relation not just to major trends but also to the reproducibility of specific claims; to recognize specific points that deserve and need further research.

In relation to the study of alteration processes of stone materials in the built environment, one of the points that seem to deserve further attention concerns the role of pore size for alteration processes such as salt weathering and freezing-thaw, given the high number of references to this feature (pore size) and the results that have cast doubts on its real importance.

There are also many results regarding the susceptibility of mineralogical, chemical, textural, and structural features of rocks. It seems clear that we are still far away from a unifying theory that can relate the alteration of stones to rock characteristics and the agents to which they are exposed in the built environment. It is possible that this will only be achieved considering a suitable lithological taxonomy, based on the relevant petrological criteria, in a multivariate perspective. Petrographic criteria should be the starting base for explaining both physical characteristics of rocks and their alteration when used as stone materials. Perhaps the most interesting results showed the potential relation of alteration to a petrographic index based on the textural and mineralogical characteristics (voids, primary minerals, and weathering products). This approach seems very promising for magmatic and metamorphic rocks and might be suitable also for low porosity sedimentary and metamorphic carbonate rocks. But additional provisions need to be included for features such as chemical susceptibility, for example for carbonate rocks, for anisotropy, especially for some silicate metamorphic rocks, and for rocks with a granular framework, such as detrital rocks and diverse limestones. The presence of heterogeneities with an extension that it is not usually in the domain of thin sections is a further potential issue to be tackled. The incorporation of factors reflecting these diverse rock features, with several terms, e.g., applied at diverse scales and for different decay agents, could lead to the formulation of a universal petrographic index for the selection of stone to be used in a built environment according to the expected alteration agents. While we are not in a position to propose an expression for such an index, it is our opinion that the subject of stone alteration is not more complex than the characterization of the engineering behavior of rock masses, for which several indexes based predominantly on macroscopic field observations have been devised (many examples can be found in [82]). The relevant index could be expressed as additions and products of ratings based on the evaluation of pertinent features such as those collected in this review, and considering also the alteration agents that could affect the stone material in the built environment.

Funding: The Lab2PT-Landscapes, Heritage and Territory laboratory-AUR/04509 is supported by the Portuguese FCT-“Fundação para a Ciência e a Tecnologia” (Portuguese funds and where applicable the FEDER co-financing, in the aim of the new partnership agreement PT2020 and COMPETE2020-POCI 010145 FEDER 007528). The authors also gratefully acknowledge the support of the CERENA (funded by a strategic project of the FCT-UID/ECI/04028/2019) and the LAMPIST of the Instituto Superior Técnico, University of Lisbon. The University Institute of Geology of the University of A Coruña (Spain) receives support from the Xunta de Galicia from the programme "Consolidación y estructuración de unidades de investigación competitivas: Grupos de potencial de crecimiento" (ED431B 2018/47) and Redes de investigación (R2017/008).

Acknowledgments: Many of the reflections presented were prompted by the Project PORENET (POCTI/CTA/44940/2002) funded by the FCT-Fundação para a Ciência e Tecnologia (Portugal). We also thank the anonymous reviewers for many contributions that contributed to the improvement of the present manuscript.

Conflicts of Interest: The authors declare no conflict of interest. The funders had no role in the design of the study; in the collection, analyses, or interpretation of data; in the writing of the manuscript, or in the decision to publish the results.

\section{References}

1. U.S. Geological Survey, Mineral Commodity Summaries, February 2019, pp. 156-157, STONE (DIMENSION). Available online: https://prd-wret.s3-us-west-2.amazonaws.com/assets/palladium/production/s3fs-public/ atoms/files/mcs-2019-stond.pdf (accessed on 30 December 2019). 
2. Herodotus. The History of Herodotus; Volume I. Translated into English by Macaulay, G.C. 1890 edition; MacMillan and Co.: London, UK; New York, NY, USA; Available online: http://www.gutenberg.org/ebooks/ 2707 (accessed on 30 December 2019).

3. Vitruvius. The Ten Books on Architecture; Translated by Morris Hicky Morgan; Harvard University Press: Cambridge, MA, USA, 1914; Available online: http://www.gutenberg.org/ebooks/20239 (accessed on 30 December 2019).

4. Stone in Architecture; Siegesmund, S.; Snethlage, R. (Eds.) Springer: Berlin/Heidelberg, Germany, 2014; ISBN 978-3-642-45154-6.

5. Vidal, F.; Vicente, R.; Mendes Silva, J. Review of environmental and air pollution impacts on built heritage: 10 questions on corrosion and soiling effects for urban intervention. J. Cult. Herit. 2019, 37, 273-295. [CrossRef]

6. Lubelli, B.; Cnudde, V.; Diaz-Goncalves, T.; Franzoni, E.; van Hees, R.P.J.; Ioannou, I.; Menendez, B.; Nunes, C.; Siedel, H.; Stefanidou, M.; et al. Towards a more effective and reliable salt crystallization test for porous building materials: State of the art. Mater. Struct. 2018, 51, 55. [CrossRef]

7. Pinna, D. Coping with Biological Growth on Stone Heritage Objects: Methods, Products, Applications, and Perspectives; AAP Apple Academic Press: Oakville, ON, Canada; Waretown, NJ, USA, 2017; ISBN 978-1-77188-532-4.

8. Ahmad, M.; Ansari, M.K.; Singh, R.; Sharma, L.K.; Singh, T.N. Assessment of durability and weathering state of some igneous and metamorphic rocks using micropetrographic index and rock durability indicators: A case study. Geotech. Geol. Eng. 2017, 35, 827-842. [CrossRef]

9. Asryan, L.; Ollé, A.; Moloney, N.; King, T.; Murray, J. Chemical alteration of lithic artefacts: An experimental case study on the effect of guano on stone flakes and its contextualization in the archaeological assemblage of azokh cave (Southern Caucasus): Chemical alteration caused by bat guano on lithic artefacts. Archaeometry 2017, 59, 981-999.

10. Barriuso, B.C.; Botticelli, G.; Cuzman, O.A.; Osticioli, I.; Tiano, P.; Matteini, M. Conservation of calcareous stone monuments: Screening different diammonium phosphate based formulations for countering phototrophic colonization. J. Cult. Herit. 2017, 27, 97-106. [CrossRef]

11. Cámara, B.; de Buergo, M.Á.; Bethencourt, M.; Fernández-Montblanc, T.; La Russa, M.F.; Ricca, M.; Fort, R. Biodeterioration of marble in an underwater environment. Sci. Total Environ. 2017, 609, 109-122. [CrossRef]

12. Carmona-Quiroga, P.M.; Jacobs, R.M.J.; Martínez-Ramírez, S.; Viles, H.A. Durability of anti-graffiti coatings on stone: Natural vs. accelerated weathering. PLoS ONE 2017, 12, e0172347. [CrossRef]

13. Comite, V.; Álvarez de Buergo, M.; Barca, D.; Belfiore, C.M.; Bonazza, A.; La Russa, M.F.; Pezzino, A.; Randazzo, L.; Ruffolo, S.A. Damage monitoring on carbonate stones: Field exposure tests contributing to pollution impact evaluation in two Italian sites. Constr. Build. Mater. 2017, 152, 907-922. [CrossRef]

14. De Kock, T.; Van Stappen, J.; Fronteau, G.; Boone, M.; De Boever, W.; Dagrain, F.; Silversmit, G.; Vincze, L.; Cnudde, V. Laminar gypsum crust on lede stone: Microspatial characterization and laboratory acid weathering. Talanta 2017, 162, 193-202. [CrossRef]

15. Germinario, L.; Siegesmund, S.; Maritan, L.; Mazzoli, C. Petrophysical and mechanical properties of Euganean trachyte and implications for dimension stone decay and durability performance. Environ. Earth Sci. 2017, 76, 739. [CrossRef]

16. Heidari, M.; Torabi-Kaveh, M.; Mohseni, H. Assessment of the effects of freeze-Thaw and salt crystallization ageing tests on Anahita temple stone, Kangavar, West of Iran. Geotech. Geol. Eng. 2017, 35, 121-136. [CrossRef]

17. Heidari, M.; Chastre, C.; Torabi-Kaveh, M.; Ludovico-Marques, M.; Mohseni, H. Application of fuzzy inference system for determining weathering degree of some monument stones in Iran. J. Cult. Herit. 2017, 25, 41-55. [CrossRef]

18. Heidari, M.; Torabi-Kaveh, M.; Chastre, C.; Ludovico-Marques, M.; Mohseni, H.; Akefi, H. Determination of weathering degree of the Persepolis stone under laboratory and natural conditions using fuzzy inference system. Constr. Build. Mater. 2017, 145, 28-41. [CrossRef]

19. Kirtzel, J.; Siegel, D.; Krause, K.; Kothe, E. Stone-eating fungi. In Advances in Applied Microbiology; Elsevier, 2017; Volume 99, pp. 83-101. ISBN 978-0-12-812050-7.

20. La Russa, M.F.; Ruffolo, S.A.; de Buergo, M.Á.; Ricca, M.; Belfiore, C.M.; Pezzino, A.; Crisci, G.M. The behaviour of consolidated Neapolitan yellow Tuff against salt weathering. Bull. Eng. Geol. Environ. 2017, 76, 115-124. [CrossRef] 
21. Mahmutoğlu, Y. Prediction of weathering by thermal degradation of a coarse-grained marble using ultrasonic pulse velocity. Environ. Earth Sci. 2017, 76, 435. [CrossRef]

22. Martinho, E.; Dionisio, A.; Mendes, M. Simulation of a portuguese limestone masonry structure submitted to fire: 3D ultrasonic tomography approach. Int. J. Conserv. Sci. 2017, 8, 565-580.

23. Navarro, R.; Cruz, A.S.; Arriaga, L.; Baltuille, J.M. Caracterización de los principales tipos de mármol extraídos en la comarca de Macael (Almería, sureste de España) y su importancia a lo largo de la historia. Bol. Geol. Min. 2017, 128, 345-393. [CrossRef]

24. Özşen, H.; Bozdağ, A.; İnce, İ. Effect of salt crystallization on weathering of pyroclastic rocks from Cappadocia, Turkey. Arab. J. Geosci. 2017, 10, 258. [CrossRef]

25. Ruffolo, S.A.; La Russa, M.F.; Ricca, M.; Belfiore, C.M.; Macchia, A.; Comite, V.; Pezzino, A.; Crisci, G.M. New insights on the consolidation of salt weathered limestone: The case study of Modica stone. Bull. Eng. Geol. Environ. 2017, 76, 11-20. [CrossRef]

26. Rusin, Z.; Świercz, P. Frost resistance of rock materials. Constr. Build. Mater. 2017, 148, 704-714. [CrossRef]

27. Sena da Fonseca, B.; Ferreira Pinto, A.P.; Piçarra, S.; Montemor, M.F. Artificial aging route for assessing the potential efficacy of consolidation treatments applied to porous carbonate stones. Mater. Des. 2017, 120, 10-21. [CrossRef]

28. Sousa, L.; Barabasch, J.; Stein, K.-J.; Siegesmund, S. Characterization and quality assessment of granitic building stone deposits: A case study of two different Portuguese granites. Eng. Geol. 2017, 221, 29-40. [CrossRef]

29. Wang, P.; Xu, J.; Fang, X.; Wang, P.; Zheng, G.; Wen, M. Ultrasonic time-frequency method to evaluate the deterioration properties of rock suffered from freeze-thaw weathering. Cold Reg. Sci. Technol. 2017, 143, 13-22. [CrossRef]

30. Xu, F.; Li, D. Modification of HBA/D230 polymer for stone protection. J. Polym. Environ. 2017, 25, 1304-1312. [CrossRef]

31. Aly, N.; Wangler, T.; Török, Á. The effect of stylolites on the deterioration of limestone: Possible mechanisms of damage evolution. Environ. Earth Sci. 2018, 77, 565. [CrossRef]

32. Auras, M.; Bundschuh, P.; Eichhorn, J.; Kirchner, D.; Mach, M.; Seewald, B.; Scheuvens, D.; Snethlage, R. Salt deposition and soiling of stone facades by traffic-induced immissions. Environ. Earth Sci. 2018, 77, 323. [CrossRef]

33. Benavente, D.; Martinez-Martinez, J.; Cueto, N.; Ordoñez, S.; Garcia-del-Cura, M.A. Impact of salt and frost weathering on the physical and durability properties of travertines and carbonate tufas used as building material. Environ. Earth Sci. 2018, 77, 147. [CrossRef]

34. Cabello Briones, C.; Viles, H. An assessment of the role of an open shelter in reducing soiling and microbial growth on the archaeological site of the bishop's palace, Witney, England. Conserv. Manag. Archaeol. Sites 2018, 20, 2-17. [CrossRef]

35. Carvalho, C.; Silva, Z.; Simão, J. Evaluation of Portuguese limestones' susceptibility to salt mist through laboratory testing. Environ. Earth Sci. 2018, 77, 523. [CrossRef]

36. Deng, H.; Yu, S.; Deng, J. Damage characteristics of sandstone subjected to coupled effect of freezing-thawing cycles and acid environment. Adv. Civ. Eng. 2018, 2018, 3560780. [CrossRef]

37. Eslami, J.; Walbert, C.; Beaucour, A.-L.; Bourges, A.; Noumowe, A. Influence of physical and mechanical properties on the durability of limestone subjected to freeze-thaw cycles. Constr. Build. Mater. 2018, 162, 420-429. [CrossRef]

38. Gibeaux, S.; Thomachot-Schneider, C.; Eyssautier-Chuine, S.; Marin, B.; Vazquez, P. Simulation of acid weathering on natural and artificial building stones according to the current atmospheric $\mathrm{SO} 2 / \mathrm{NO} \times$ rate. Environ. Earth Sci. 2018, 77, 327. [CrossRef]

39. Gibeaux, S.; Vázquez, P.; De Kock, T.; Cnudde, V.; Thomachot-Schneider, C. Weathering assessment under X-ray tomography of building stones exposed to acid atmospheres at current pollution rate. Constr. Build. Mater. 2018, 168, 187-198. [CrossRef]

40. Grossi, D.; Del Lama, E.A. Avaliação da eficácia de hidrofugantes e antigraffiti no Arenito Itararé. Geol. USP Sér. Cient. 2018, 18, 43-55. [CrossRef]

41. Hashemi, M.; Bashiri Goudarzi, M.; Jamshidi, A. Experimental investigation on the performance of Schmidt hammer test in durability assessment of carbonate building stones against freeze-thaw weathering. Environ. Earth Sci. 2018, 77, 684. [CrossRef] 
42. Ksinopoulou, E.; Bakolas, A.; Moropoulou, A. Consolidation effectiveness of modified Si-based nanocomposites applied to limestones. Mater. Struct. 2018, 51, 156. [CrossRef]

43. Martínez-Martínez, J.; Pola, A.; García-Sánchez, L.; Reyes Agustin, G.; Osorio Ocampo, L.S.; Macías Vázquez, J.L.; Robles-Camacho, J. Building stones used in the architectural heritage of Morelia (México): Quarries location, rock durability and stone compatibility in the monument. Environ. Earth Sci. 2018, 77, 167. [CrossRef]

44. Misra, A.; Franco Castillo, I.; Müller, D.P.; González, C.; Eyssautier-Chuine, S.; Ziegler, A.; de la Fuente, J.M.; Mitchell, S.G.; Streb, C. Polyoxometalate-ionic liquids (POM-ILs) as anticorrosion and antibacterial coatings for natural stones. Angew. Chem. Int. Ed. 2018, 57, 14926-14931. [CrossRef]

45. Murru, A.; Freire-Lista, D.M.; Fort, R.; Varas-Muriel, M.J.; Meloni, P. Evaluation of post-thermal shock effects in carrara marble and santa caterina di pittinuri limestone. Constr. Build. Mater. 2018, 186, 1200-1211. [CrossRef]

46. Pötzl, C.; Dohrmann, R.; Siegesmund, S. Clay swelling mechanism in tuff stones: An example of the Hilbersdorf Tuff from Chemnitz, Germany. Environ. Earth Sci. 2018, 77, 188. [CrossRef]

47. Pötzl, C.; Siegesmund, S.; Dohrmann, R.; Koning, J.M.; Wedekind, W. Deterioration of volcanic tuff rocks from Armenia: Constraints on salt crystallization and hydric expansion. Environ. Earth Sci. 2018, 77, 660. [CrossRef]

48. Rembiś, M.; Dubiniewicz, A. Zmiany mikrostrukturalne w płytach skał magmowych poddanych termicznej obróbce metoda płomieniowania. Przegląd Geol. 2018, 66, 450-456. [CrossRef]

49. Sato, M.; Hattanji, T. A laboratory experiment on salt weathering by humidity change: Salt damage induced by deliquescence and hydration. Prog. Earth Planet. Sci. 2018, 5, 84. [CrossRef]

50. Scrivano, S.; Gaggero, L.; Gisbert Aguilar, J. Micro-porosity and minero-petrographic features influences on decay: Experimental data from four dimension stones. Constr. Build. Mater. 2018, 173, 342-349. [CrossRef]

51. Siegesmund, S.; Sousa, L.; Knell, C. Thermal expansion of granitoids. Environ. Earth Sci. 2018, 77, 41. [CrossRef]

52. Sousa, L.; Siegesmund, S.; Wedekind, W. Salt weathering in granitoids: An overview on the controlling factors. Environ. Earth Sci. 2018, 77, 502. [CrossRef]

53. Stück, H.L.; Platz, T.; Müller, A.; Siegesmund, S. Natural stones of the Saale-Unstrut Region (Germany): Petrography and weathering phenomena. Environ. Earth Sci. 2018, 77, 300. [CrossRef]

54. Suzuki, A.; Vettori, S.; Giorgi, S.; Carretti, E.; Di Benedetto, F.; Dei, L.; Benvenuti, M.; Moretti, S.; Pecchioni, E.; Costagliola, P. Laboratory study of the sulfation of carbonate stones through SWIR hyperspectral investigation. J. Cult. Herit. 2018, 32, 30-37. [CrossRef]

55. Tiennot, M.; Mertz, J.-D.; Bourgès, A. Sensitivity of kersantite toughness to moisture: Influence of the phyllosilicates. Environ. Earth Sci. 2018, 77, 483. [CrossRef]

56. Wedekind, W.; Gross, C.J.; Hoffmann, A.; Siegesmund, S. Damage phenomenon and petrophysical properties of sandstones at the Phnom Bakheng Temple (Angkor, Cambodia): First investigations and possible conservation measures. Environ. Earth Sci. 2018, 77, 735. [CrossRef]

57. Yagiz, S. The effect of $\mathrm{pH}$ of the testing liquid on the degradability of carbonate rocks. Geotech. Geol. Eng. 2018, 36, 2351-2363. [CrossRef]

58. Zalooli, A.; Freire-Lista, D.M.; Khamehchiyan, M.; Nikudel, M.R.; Fort, R.; Ghasemi, S. Ghaleh-khargushi rhyodacite and Gorid andesite from Iran: Characterization, uses, and durability. Environ. Earth Sci. 2018, 77, 315. [CrossRef]

59. Zarzuela, R.; Moreno-Garrido, I.; Blasco, J.; Gil, M.L.A.; Mosquera, M.J. Evaluation of the effectiveness of $\mathrm{CuONPs} / \mathrm{SiO} 2-$ based treatments for building stones against the growth of phototrophic microorganisms. Constr. Build. Mater. 2018, 187, 501-509. [CrossRef]

60. Zhou, Z.; Cai, X.; Ma, D.; Chen, L.; Wang, S.; Tan, L. Dynamic tensile properties of sandstone subjected to wetting and drying cycles. Constr. Build. Mater. 2018, 182, 215-232. [CrossRef]

61. Çelik, M.Y.; Aygün, A. The effect of salt crystallization on degradation of volcanic building stones by sodium sulfates and sodium chlorides. Bull. Eng. Geol. Environ. 2019, 78, 3509-3529. [CrossRef]

62. Dursun, F.; Topal, T. Durability assessment of the basalts used in the Diyarbakır City Walls, Turkey. Environ. Earth Sci. 2019, 78, 456. [CrossRef]

63. ElBaghdady, K.Z.; Tolba, S.T.; Houssien, S.S. Biogenic deterioration of Egyptian limestone monuments: Treatment and conservation. J. Cult. Herit. 2019, 38, 118-125. [CrossRef] 
64. Farkas, O.; Török, Á. Effect of exhaust gas on natural stone tablets, a laboratory experiment. Period. Polytech. Civil. Eng. 2019, 63, 115-120. [CrossRef]

65. Fogue-Djombou, Y.I.; Corn, S.; Clerc, L.; Salze, D.; Garcia-Diaz, E. Freeze-thaw resistance of limestone roofing tiles assessed through impulse vibration monitoring and finite element modeling in relation to their microstructure. Constr. Build. Mater. 2019, 205, 656-667. [CrossRef]

66. Geng, H.; Zhang, S.; Zhi, J.; Zhang, R.; Ren, J.; Ro, C.-U. Acid solution decreases the compressional wave velocity of sandstone from the Yungang Grottoes, Datong, China. Herit. Sci. 2019, 7, 4. [CrossRef]

67. Germinario, L.; Török, Á. Variability of technical properties and durability in volcanic tuffs from the same quarry region-Examples from Northern Hungary. Eng. Geol. 2019, 262, 105319. [CrossRef]

68. Korobiichuk, V.; Shlapak, V.; Kryvoruchko, A.; Sobolevskyi, R.; Zuievska, N. Analysis of change in the decorative properties of granites under thermal exposure. East. Eur. J. Adv. Technol. 2019, 2, 35-43. [CrossRef]

69. Martínez-Martínez, J.; Benavente, D.; Pérez-Huerta, A.; Cueto, N.; García-del-Cura, M.A. Changes on the surface properties of foliated marbles at different cutting orientations. Constr. Build. Mater. 2019, 222, 493-499. [CrossRef]

70. Montiel-Zafra, V.; Canadas-Quesada, F.; Campos-Suñol, M.J.; Vera-Candeas, P.; Ruiz-Reyes, N. Monitoring the internal quality of ornamental stone using impact-echo testing. Appl. Acoust. 2019, 155, 180-189. [CrossRef]

71. Nasri, F.; Boumezbeur, A.; Benavente, D. Influence of the petrophysical and durability properties of carbonate rocks on the deterioration of historic constructions in Tebessa (northeastern Algeria). Bull. Eng. Geol. Environ. 2019, 78, 3969-3981. [CrossRef]

72. Navarro, R.; Catarino, L.; Pereira, D.; Gil, F.P. de S.C. Effect of UV radiation on chromatic parameters in serpentinites used as dimension stones. Bull. Eng. Geol. Environ. 2019, 78, 5345-5355. [CrossRef]

73. Pozo-Antonio, J.S.; Otero, J.; Alonso, P.; Barberà, X.M. Nanolime- and nanosilica-based consolidants applied on heated granite and limestone: Effectiveness and durability. Constr. Build. Mater. 2019, 201, 852-870. [CrossRef]

74. Scrivano, S.; Gaggero, L.; Gisbert Aguilar, J. An experimental investigation of the effects of grain size and pore network on the durability of Vicenza stone. Rock Mech. Rock Eng. 2019, 52, 2935-2948. [CrossRef]

75. Sun, Q.; Dong, Z.; Jia, H. Decay of sandstone subjected to a combined action of repeated freezing-thawing and salt crystallization. Bull. Eng. Geol. Environ. 2019, 78, 5951-5964. [CrossRef]

76. Thomachot-Schneider, C.; Vázquez, P.; Gommeaux, M.; Lelarge, N.; Conreux, A.; Drothière, X.; Mouhoubi, K.; Bodnar, J.-L. Thermal response of building stones contaminated with salts. Constr. Build. Mater. 2019, 226, 331-344. [CrossRef]

77. Tiennot, M.; Mertz, J.-D.; Bourgès, A. Influence of Clay Minerals nature on the hydromechanical and fracture behaviour of stones. Rock Mech. Rock Eng. 2019, 52, 1599-1611. [CrossRef]

78. Torabi-Kaveh, M.; Heidari, M.; Mohseni, H.; Ménendez, B. Role of petrography in durability of limestone used in construction of Persepolis complex subjected to artificial accelerated ageing tests. Environ. Earth Sci. 2019, 78, 297. [CrossRef]

79. Török, Á.; Szemerey-Kiss, B. Freeze-thaw durability of repair mortars and porous limestone: Compatibility issues. Prog. Earth Planet. Sci. 2019, 6, 42. [CrossRef]

80. Uğur, İ; Toklu, H.Ö. Effect of multi-cycle freeze-thaw tests on the physico-mechanical and thermal properties of some highly porous natural stones. Bull. Eng. Geol. Environ. 2019. [CrossRef]

81. Zalooli, A.; Khamehchiyan, M.; Nikudel, M.R. Durability assessment of Gerdoi and red travertines from Azarshahr, East Azerbaijan province, Iran. Bull. Eng. Geol. Environ. 2019, 78, 1683-1695. [CrossRef]

82. Singh, B.; Goel, R.K. Rock Mass Classification: A Practical Approach in Civil Engineering, 1st ed.; Elsevier: Amsterdam, The Netherlands; New York, NY, USA, 1999; ISBN 9780080430133.

(C) 2020 by the authors. Licensee MDPI, Basel, Switzerland. This article is an open access article distributed under the terms and conditions of the Creative Commons Attribution (CC BY) license (http://creativecommons.org/licenses/by/4.0/). 